\title{
Fibronectin-, vitronectin- and laminin-binding proteins at the cell walls of Candida parapsilosis and Candida tropicalis pathogenic yeasts
}

Andrzej Kozik*, Justyna Karkowska-Kuleta', Dorota Zajac ${ }^{1}$, Oliwia Bochenska', Sylwia Kedracka-Krok², Urszula Jankowska ${ }^{3}$ and Maria Rapala-Kozik ${ }^{1}$

\begin{abstract}
Background: Candida parapsilosis and C. tropicalis increasingly compete with C. albicans - the most common fungal pathogen in humans - as causative agents of severe candidiasis in immunocompromised patients. In contrast to C. albicans, the pathogenic mechanisms of these two non-albicans Candida species are poorly understood. Adhesion of Candida yeast to host cells and the extracellular matrix is critical for fungal invasion of hosts.
\end{abstract}

Methods: The fungal proteins involved in interactions with extracellular matrix proteins were isolated from mixtures of $\beta$-1,3-glucanase- or $\beta-1,6$-glucanase-extractable cell wall-associated proteins by use of affinity chromatography and chemical cross-linking methods, and were further identified by liquid chromatography-coupled tandem mass spectrometry.

Results: In the present study, we characterized the binding of three major extracellular matrix proteins-fibronectin, vitronectin and laminin - to C. parapsilosis and C. tropicalis pseudohyphae. The major individual compounds of the fungal cell wall that bound fibronectin, vitronectin and laminin were found to comprise two groups: (1) true cell wall components similar to C. albicans adhesins from the Als, Hwp and Iff/Hyr families; and (2) atypical (cytoplasmderived) surface-exposed proteins, including malate synthase, glucose-6-phosphate isomerase, 6-phosphogluconate dehydrogenase, enolase, fructose-1,6-bisphosphatase, transketolase, transaldolase and elongation factor 2.

Discussion: The adhesive abilities of two investigated non-albicans Candida species toward extracellular matrix proteins were comparable to those of $C$. albicans suggesting an important role of this particular virulence attribute in the pathogenesis of infections caused by $C$. tropicalis and C. parapsilosis.

Conclusions: Our results reveal new insight into host-pathogen interactions during infections by two important, recently emerging, fungal pathogens.

Keywords: Non-albicans Candida species, Candidiasis, Extracellular matrix, Fibronectin, Vitronectin, Laminin

\footnotetext{
* Correspondence: andrzej.kozik@uj.edu.pl

'Department of Analytical Biochemistry, Faculty of Biochemistry, Biophysics and Biotechnology, Jagiellonian University in Krakow, Gronostajowa 7, 30-387 Krakow, Poland

Full list of author information is available at the end of the article
} 


\section{Background}

Several species of yeasts from the genus Candida can cause mild-to-severe infections that are a serious threat to the growing number of individuals with immunological impairment, such as patients subjected to surgery, transplantations, total parenteral nutrition, and insertion of catheters or stents; people after broad-spectrum antimicrobial therapy, chemotherapy, or steroid treatment [1-3]; cancer patients [4]; and neonates and the elderly [5, 6]. The epidemiological data concerning the frequency of candidiasis caused by particular species repeatedly indicate that Candida albicans is the most widely distributed opportunistic yeast pathogen in patients with a weakened immune system; however, other Candida species, including C. glabrata, C. parapsilosis, C. tropicalis, and C. krusei, collectively called non-albicans Candida (NAC) species, are increasingly emerging as causative agents of invasive mycoses [7-10]. A recent study showed that C. albicans and NAC species currently nearly equally contribute to the rate of invasive bloodstream candidal infections in the United States [11], whereas other reports (data of the Prospective Antifungal Therapy Alliance [PATH Alliance ${ }^{\circledast}$ registry) suggested that the proportion of candidemia caused by NAC species even exceeds that of $C$. albicans-dependent infections (58 \% vs. $42 \%$ ) [12]. Therefore, molecular studies into the pathogenesis of NAC species-dependent candidiasis should urgently be intensified, additionally because the underlying mechanisms might differ in many aspects from those well recognized for $C$. albicans $[13,14]$.

One important phenomenon to be considered with regard to the pathogenesis of fungal infections is the ability of the pathogen to adhere to different surfaces, including both artificial surfaces of medical devices and host cells and proteins. Generally, the first step of pathogen invasion involves the destruction of mechanical barriers that provide passive and active resistance against further microbe dissemination in the host organism. A barrier composed of a thin layer of epithelial or endothelial cells, strengthened with extracellular matrix (ECM), must be impaired during this process. During barrier impairment, an essential role is played by adhesive proteins exposed on the pathogen surface and hydrolytic enzymes secreted by the pathogen cells into the environment.

The interactions of ECM components with molecules that are exposed on the cell surface of pathogenic bacteria, also called the microbial surface components recognizing adhesive matrix molecules (MSCRAMM), have been extensively characterized [15]. C. albicans also exposes at the cells surface a set of adhesive proteins that interact with the major ECM proteins (ECMPs), including laminin, fibronectin, collagen type IV, and vitronectin. The ECMPbinding candidal proteins include typical glycosylphosphatidylinositol (GPI)-anchored adhesins/invasins from the agglutinin-like sequence (Als) family (i.e., Als1, Als3 and
Als5) [16], as well as some proteins non-covalently bound to the cell wall, such as alcohol dehydrogenase (Adh1) [17] and glyceraldehyde 3-phosphate dehydrogenase (Tdh3) [18]. In other species from the genus Candida, many predicted adhesin-like proteins, potentially capable of interacting with host proteins, were indicated through a computational analysis of the genome [19]. Unfortunately, their exposure on the yeast cell surface and actual binding affinity for ECMPs have not been studied with biochemical methods, with the notable exception of the identification of a $105-\mathrm{kDa}$ fibronectin-binding protein on the C. tropicalis cell surface [20]. The current study aimed to characterize the binding of fibronectin, laminin and vitronectin to the cell walls of $C$. parapsilosis and $C$. tropicalis-two prominent emerging fungal pathogens from the NAC group-and to identify the sets of fungal cell wall-associated proteins involved in this process.

\section{Methods}

\section{Yeast strains and culturing}

The C. albicans strain ATCC $10231^{\mathrm{TM}}$, C. parapsilosis strain CDC 317 (ATCC ${ }^{\oplus}$ MYA-4646 ${ }^{\mathrm{TM}}$ ) and C. tropicalis strain T1 (ATCC ${ }^{\oplus}$ MA-3404 ${ }^{\mathrm{mm}}$ ) were purchased from American Type Culture Collection (Manassas, VA). Cells were cultured in YPD broth (1\% yeast extract, $2 \%$ soybean peptone and $2 \%$ glucose) (Sigma, St. Louis, MO) at $30{ }^{\circ} \mathrm{C}$ for $16 \mathrm{~h}$ and then, to induce hyphae (C. albicans) or pseudohyphae $\left(C\right.$. parapsilosis and C. tropicalis) formation, at $37{ }^{\circ} \mathrm{C}$ in RPMI 1640 medium (PAA Laboratories $\mathrm{GmbH}$, Pasching, Austria) for 3 or $72 \mathrm{~h}$.

\section{Proteins}

Human fibronectin and vitronectin were purchased from R\&D Systems (Minneapolis, MN), human laminin from Millipore (Temecula, CA), $\beta$-1,6-glucanase from Takara Bio Inc. (Otsu, Shiga, Japan), $\beta$-1,3-glucanase (lyticase) from Sigma and $\alpha 1-2,3$ mannosidase and $\alpha 1-6$ mannosidase from New England Biolabs (Ipswich, MA). Proteinase $\mathrm{K}$ and bovine serum albumin (BSA) were obtained from BioShop Canada Inc. (Burlington, Ontario, Canada), trypsin from Promega (Madison, WI) or Biocentrum (Krakow, Poland) and horseradish peroxidase-conjugated streptavidin solution (SA-HRP) from MP Biomedicals (Solon, OH).

\section{Biotinylation of ECMPs}

A solution $(1 \mathrm{mg} / 100 \mu \mathrm{l})$ of biotin $\mathrm{N}$-hydroxysuccinimide ester (NHS-biotin; Sigma) in dimethylformamide was added to fibronectin, vitronectin and laminin (50 $\mu \mathrm{g}$ each) in $100 \mu \mathrm{l}$ of $0.1 \mathrm{M}$ bicarbonate buffer, $\mathrm{pH}$ 8.3. The mixture was incubated at $4{ }^{\circ} \mathrm{C}$ for $4 \mathrm{~h}$ and then dialyzed against phosphate-buffered saline (PBS) at $4{ }^{\circ} \mathrm{C}$ for $24 \mathrm{~h}$. ECMPs to be used for the binding assays were biotinylated with $10 \mu \mathrm{g}$ NHS-biotin per $50 \mu \mathrm{g}$ protein, whereas for the 
chemical cross-linking experiments a 3 -fold lower reagent:protein ratio was applied.

\section{Biotinylation of cell wall-associated proteins of filamentous forms of Candida spp.}

To biotinylate the proteins associated with the fungal cell wall, $0.4 \mathrm{~g}$ (wet weight) of the C. albicans hyphal forms or C. parapsilosis and C. tropicalis pseudohyphal forms was washed twice with $0.1 \mathrm{M}$ bicarbonate buffer, $\mathrm{pH} 8.3$, suspended in $1 \mathrm{ml}$ of the same buffer and treated with NHS-biotin ( $1 \mathrm{mg}$ in $50 \mu \mathrm{l}$ dimethylformamide) for $1 \mathrm{~h}$ in the dark at room temperature. Excess reagent was then removed by two washes in $50 \mathrm{mM}$ phosphate buffer $(\mathrm{pH}$ 6.0).

\section{Extraction of cell wall-associated proteins from filamentous forms of Candida spp.}

The cell wall-associated proteins were extracted from both biotinylated and non-biotinylated hyphae/pseudohyphae (see above). Isolation with $\beta$-1,3-glucanase was preceded by washing the fungal cells twice with $10 \mathrm{mM}$ Tris $-\mathrm{HCl}$ buffer with $0.9 \% \mathrm{NaCl}, \mathrm{pH} 7.4$ and twice with $50 \mathrm{mM}$ Tris- $\mathrm{HCl}$ buffer, $\mathrm{pH}$ 7.5. Next, the cells were suspended in $1 \mathrm{ml}$ of the second buffer (supplemented with protease inhibitor mixture [Roche, Basel, Switzerland]) and treated with $40 \mathrm{mM} \beta$-mercaptoethanol and $500 \mathrm{U}$ of $\beta$-1,3-glucanase for $24 \mathrm{~h}$ at $37^{\circ} \mathrm{C}$. To extract the proteins using $\beta-1,6$ glucanase, the cells were first washed three times with Mcllvaine buffer (a mixture of $0.1 \mathrm{M}$ citric acid and $0.2 \mathrm{M}$ disodium phosphate), $\mathrm{pH}$ 6.0, with $0.5 \mathrm{M}$ sodium tartrate (an osmotic stabilizer). The cells were then suspended in $1 \mathrm{ml}$ of the same buffer (supplemented with protease inhibitors) and treated with $0.8 \mathrm{U}$ of $\beta$-1,6-glucanase for $24 \mathrm{~h}$ at $37^{\circ} \mathrm{C}$.

After both types of extraction, the supernatants were collected and dialyzed against phosphate-buffered saline (PBS), $\mathrm{pH} 7.4$, at $4{ }^{\circ} \mathrm{C}$ for $48 \mathrm{~h}$, and the cell membrane integrity of the remaining cells was tested by staining with SYTOX $^{\bullet}$ Green (Invitrogen Life Technologies, Carlsbad, CA) and Trypan Blue (Sigma). The protein concentrations in the obtained protein mixtures were determined [21] and the extracts were characterized by sodium dodecyl sulphate-polyacrylamide gel electrophoresis (SDS-PAGE) in the Laemmli system [22].

\section{Analysis of the binding of biotinylated fibronectin, vitronectin and laminin to filamentous forms of Candida spp.}

Hyphal or pseudohyphal forms of C. albicans, C. parapsilosis or C. tropicalis which adhered to the wells of MaxiSorp 96-well microplates (Sarstedt, Nümbrecht, Germany), were obtained from $1 \times 10^{6}$ cells propagated in RPMI 1640 medium at $37^{\circ} \mathrm{C}$ for $3 \mathrm{~h}$. Each step of the following binding assay was preceded by washing the fungal cells three times with PBS buffer containing $1 \%$ BSA. The unoccupied surfaces of the microplate wells were blocked with $3 \%$ BSA in PBS at $4{ }^{\circ} \mathrm{C}$ overnight. The wells without fungal cells (with the surface blocked with BSA) served as controls. Solutions of biotinylated fibronectin, vitronectin and laminin $(50 \mu \mathrm{l})$ were added to the cells and incubated at $37{ }^{\circ} \mathrm{C}$ for $1.5 \mathrm{~h}$ with gentle shaking. The amounts of bound biotinylated proteins were determined with the use of a SA-HRP/TMB detection system as described previously [23]. The values obtained for control samples were subtracted from the total binding values.

\section{Binding of biotinylated fibronectin, vitronectin and} laminin to C. parapsilosis and C. tropicalis pseudohyphal forms pretreated with mannosidases, proteinase $\mathrm{K}$ and $\beta$-1,3-glucanase

C. parapsilosis and C. tropicalis cells $\left(5 \times 10^{8}\right)$ were grown in RPMI 1640 medium to obtain pseudohyphal forms and then were incubated at $37{ }^{\circ} \mathrm{C}$ for $1 \mathrm{~h}$ in a testtube with $100 \mu \mathrm{l}$ of: (1) a mixture of $64 \mathrm{U}$ of $\alpha 1-2,3$ mannosidase and $80 \mathrm{U}$ of $\alpha 1-6$ mannosidase in $50 \mathrm{mM}$ sodium acetate buffer with $5 \mathrm{mM} \mathrm{CaCl}_{2}, \mathrm{pH} 5.5$; (2) $0.05 \mathrm{mg} / \mathrm{ml}$ proteinase $\mathrm{K}$ in $20 \mathrm{mM}$ Tris $-\mathrm{HCl}$ buffer with $20 \mathrm{mM} \mathrm{NaCl}, 2 \mathrm{mM} \mathrm{MgCl} 2,0.1 \mathrm{M} \mathrm{DTT}, 1 \mathrm{mM}$ $\mathrm{CaCl}_{2}, \mathrm{pH} 8.0$; or (3) $0.12 \mathrm{mg} / \mathrm{ml} \beta$-1,3-glucanase and $40 \mathrm{mM} \beta$-mercaptoethanol in $50 \mathrm{mM}$ Tris buffer, $\mathrm{pH}$ 7.5. The cell viability (i.e., cell membrane integrity) after these treatments was checked with SYTOX $^{\circ}$ Green. The cells were washed three times with $1 \%$ BSA in PBS and then a $100 \mathrm{nM}$ solution of biotinylated ECMP $(50 \mu \mathrm{l})$ was added to each tube and the tubes were incubated at $37{ }^{\circ} \mathrm{C}$ for $1 \mathrm{~h}$. The amount of bound labeled protein was determined as described above.

\section{Tests for binding of Candida spp. cell wall-associated proteins to ECMPs}

For the saturation binding tests, fibronectin, vitronectin and laminin were immobilized in wells of MaxiSorp 96-well microplates (Sarstedt) by overnight incubation at $4{ }^{\circ} \mathrm{C}(5 \mathrm{pmol}$ protein in total volume of $50 \mu \mathrm{l}$ per well). After this step and all subsequent steps, the wells were washed three times with $1 \%$ BSA in PBS. The unoccupied surfaces in each well were blocked with $3 \%$ BSA in PBS at $4{ }^{\circ} \mathrm{C}$ (overnight). Solutions of biotinylated fungal cell wall-associated proteins $(50 \mu \mathrm{l})$ were added to the wells and the plate was incubated at $37^{\circ} \mathrm{C}$ for $1.5 \mathrm{~h}$. In an alternative competitive variant of this assay, the microplate-immobilized ECMP (3 pmol fibronectin or $1.25 \mathrm{pmol}$ of vitronectin or laminin in total volume of $50 \mu \mathrm{l}$ ) competed with soluble ECMP, added in increasing molar excess, for binding to biotinylated fungal cell wall-associated proteins. In both types of assay, the binding level was detected with the SA-HRP/TMB detection system. 


\section{Affinity chromatographic isolation of fungal cell wall-associated proteins that bind fibronectin, vitronectin or laminin}

Affinity gels with covalently conjugated fibronectin, vitronectin or laminin were prepared as described previously [24]. Protein immobilization proceeded in 0.1 M HEPES buffer with $80 \mathrm{mM} \mathrm{CaCl}_{2}$, pH 7.5. The $\beta$-1,3-glucanase- or $\beta$-1,6-glucanase-extracted C. parapsilosis or C. tropicalis cell wall-associated proteins $(300 \mu \mathrm{g}$ protein in $300 \mu \mathrm{l} \mathrm{PBS}$, with protease inhibitors) were incubated at $37{ }^{\circ} \mathrm{C}$ for $4 \mathrm{~h}$ with $50 \mu \mathrm{l}$ of the appropriate affinity gel. To remove unbound proteins, the gel was washed five times with $1 \mathrm{ml}$ PBS. Bound proteins were eluted during the gel incubation with $30 \mu \mathrm{l} 2 \% \mathrm{SDS}$ at $95{ }^{\circ} \mathrm{C}$ for $20 \mathrm{~min}$. The obtained mixtures of ECMP-binding fungal proteins were separated by SDS-PAGE, with gel staining with Coomassie Brilliant Blue R-250. Control samples of the gel, not coupled to any ECMP (with reactive groups blocked with ethanolamine) but incubated with fungal proteins, were also prepared.

\section{Selection of fibronectin-, vitronectin- and laminin-binding fungal proteins by chemical cross-linking}

Biotinylated ECMPs $(20 \mu \mathrm{g}$ in $100 \mu \mathrm{l}$ PBS, pH 7.4) were incubated in the dark at $4{ }^{\circ} \mathrm{C}$ for $2 \mathrm{~h}$ with $0.5 \mathrm{mM}$ sulfosuccinimidyl 2-([4,4' -azipentanamido]ethyl)-1,3' -dithiopropionate (sulfo-SDAD) (Thermo Fisher Scientific Inc., Woltham, MA). The reaction was stopped with $50 \mathrm{mM}$ Tris for $15 \mathrm{~min}$ and the excess reagent was removed by dialysis against PBS at $4{ }^{\circ} \mathrm{C}$ overnight in the dark. The particular labeled ECMP was incubated with a mixture of fungal cell wall-associated proteins $(300 \mu \mathrm{g}$ in $300 \mu \mathrm{l}$ PBS) at $37{ }^{\circ} \mathrm{C}$ for $1 \mathrm{~h}$ in the dark. The samples were placed on ice and exposed to UV radiation (365 nm) for $15 \mathrm{~min}$. Covalently linked pairs of biotinylated ECMP-fungal protein were adsorbed on MagnaBind Streptavidin Beads (Thermo Fisher Scientific Inc.). The beads were washed five times with $1 \mathrm{ml}$ PBS, with intense stirring, to remove unbound, unlabeled proteins. The fungal proteins were dissociated from the beads by boiling for $30 \mathrm{~min}$ in $30 \mu \mathrm{l} 2.5 \% \beta$-mercaptoethanol and $2 \%$ SDS. These proteins were separated by SDSPAGE, and protein bands were visualized by staining with Coomassie Brilliant Blue R-250.

\section{Protein identification by mass spectrometry}

To identify the proteins in the stained bands after SDSPAGE, gel pieces were manually excised, destained at $37{ }^{\circ} \mathrm{C}$ by several washes in $25 \%$ and $50 \%$ acetonitrile, reduced with $50 \mathrm{mM}$ dithiothreitol at $56{ }^{\circ} \mathrm{C}$ for $45 \mathrm{~min}$ and alkylated with $55 \mathrm{mM}$ iodoacetamide at room temperature for $2 \mathrm{~h}$ in the dark. Residual reagents were removed with $50 \%$ acetonitrile in $25 \mathrm{mM}$ ammonium bicarbonate buffer $\left(\mathrm{NH}_{4} \mathrm{HCO}_{3}\right)$. Gel pieces were dehydrated in $100 \%$ acetonitrile and dried for 15 min using a SpeedVac. Next, $15 \mu \mathrm{l}$ of trypsin solution ( $10 \mathrm{ng} / \mu \mathrm{l}$ in $25 \mathrm{mM} \mathrm{NH}_{4} \mathrm{HCO}_{3}, \mathrm{pH}$ 8.0) was added for $15 \mathrm{~min}$ and an additional $20 \mu \mathrm{l}$ of $25 \mathrm{mM}$ $\mathrm{NH}_{4} \mathrm{HCO}_{3}$ was then added. The digestion was performed at $37{ }^{\circ} \mathrm{C}$ overnight. Peptides were extracted by sonication and drying with $100 \%$ acetonitrile. The extracts were evaporated to dryness and resuspended in $2 \%$ acetonitrile with $0.05 \%$ trifluoroacetic acid or $10 \%$ acetonitrile with $0.1 \%$ formic acid.

Two methods were used for peptide analysis by liquid chromatography-coupled tandem mass spectrometry (LC-MS/MS). One method used an UltiMate 3000 RSLCnano System (Dionex, Carlsbad, CA), coupled to a micrOTOF-QII mass spectrometer (Bruker, Bremen, Germany), containing an Apollo Source ESI nano-sprayer equipped with low-flow nebulizer. The peptide mixtures were injected on a C18 precolumn (Acclaim PepMap Nano Trap Column) using $2 \%$ acetonitrile with $0.05 \%$ formic acid as a mobile phase and further separated on a $15 \mathrm{~cm} \times 75 \mu \mathrm{m}$ reversed-phase column (Acclaim PepMap $75 \mu \mathrm{m} 100 \AA$ A Nano Series TM Column) using a gradient of 2-40\% acetonitrile with $0.05 \%$ trifluoroacetic acid in $30 \mathrm{~min}$. The mass spectrometer was operated in a standard data-dependent acquisition MS/MS mode, with fragmentation of the most intensive precursor ions.

The second method for LS-MS/MS analysis used a HCT Ultra ion-trap mass spectrometer equipped with an electrospray ionization ion source and electron transfer dissociation II fragmentation module (Bruker, Bremen, Germany) and coupled to an ultrahighperformance liquid chromatography Dionex Ultimate 3000 system. The peptides were separated on a $100 \mathrm{~mm} \times 2.1 \mathrm{~mm}$ Accucore C18 column (particle size, $2.6 \mu \mathrm{m})$ (Thermo Fisher Scientific), with a gradient of $10-70 \%$ of $0.1 \%$ formic acid in $80 \%$ acetonitrile in $38 \mathrm{~min}$. The mass spectrometer was operated in a standard MS/MS mode with simultaneous fragmentation of the most intensive precursor ions by collisioninduced dissociation and electron transfer dissociation.

Measured MS spectra were recalibrated using fragment ions of trypsin-derived peptides.

Mascot Generic format (.mgf) files were generated by pre-processing the raw data with Data Analysis 4.0 software (Bruker). The lists of peaks obtained were searched against the nonredundant protein database of the NCBI (all entries: 53,183,920 sequences) or with taxonomy restriction (Fungi: 3,246,022 sequences) using an in-house Mascot server (v.2.3.0; Matrix Science, London, UK). The following search parameters were applied: enzyme specificity - trypsin; permitted number of missed cleavages -1 ; fixed modification - carbamidomethylation (C); variable modifications - oxidation $(\mathrm{M})$; protein mass - unrestricted; peptide mass tolerance of $\pm 20 \mathrm{ppm}$ or $\pm 0.3 \mathrm{Da}$ and fragment mass tolerance of $\pm 0.05 \mathrm{Da}$ or $\pm 0.3 \mathrm{Da}$, for the two LC-MS/MS systems specified above, respectively. 


\section{Ethics statement}

No ethical approval was required for this study since it did not involve humans, human data or animals.

\section{Results}

General characteristics of the binding of biotinylated fibronectin, vitronectin and laminin by filamentous forms of Candida spp.

Representative plots for saturable binding of biotin-labeled fibronectin by C. albicans hyphae and C. parapsilosis and C. tropicalis pseudohyphae are shown in Fig. 1a. The binding levels were within a range of 8-20 fmoles for hyphae/ pseudohyphae generated from $1 \times 10^{6}$ cells, and decreased in the order of C. albicans $>$ C. tropicalis $>$ C. parapsilosis. The binding of vitronectin and laminin by $C$. parapsilosis and C. tropicalis pseudohyphae is shown in Fig. $1 \mathrm{~b}$. For each of the latter species, the binding capacities for fibronectin and laminin were comparable; for vitronectin, they were slightly higher in C. parapsilosis and lower in C. tropicalis. The highest ( $>2$-fold) difference in binding capacity was noted between the two species for vitronectin.

Involvement of major classes of fungal cell wall components, namely, cell wall-associated proteins, glucans and mannans, was tested by determination of the binding of each ECMP to pseudohyphae that were
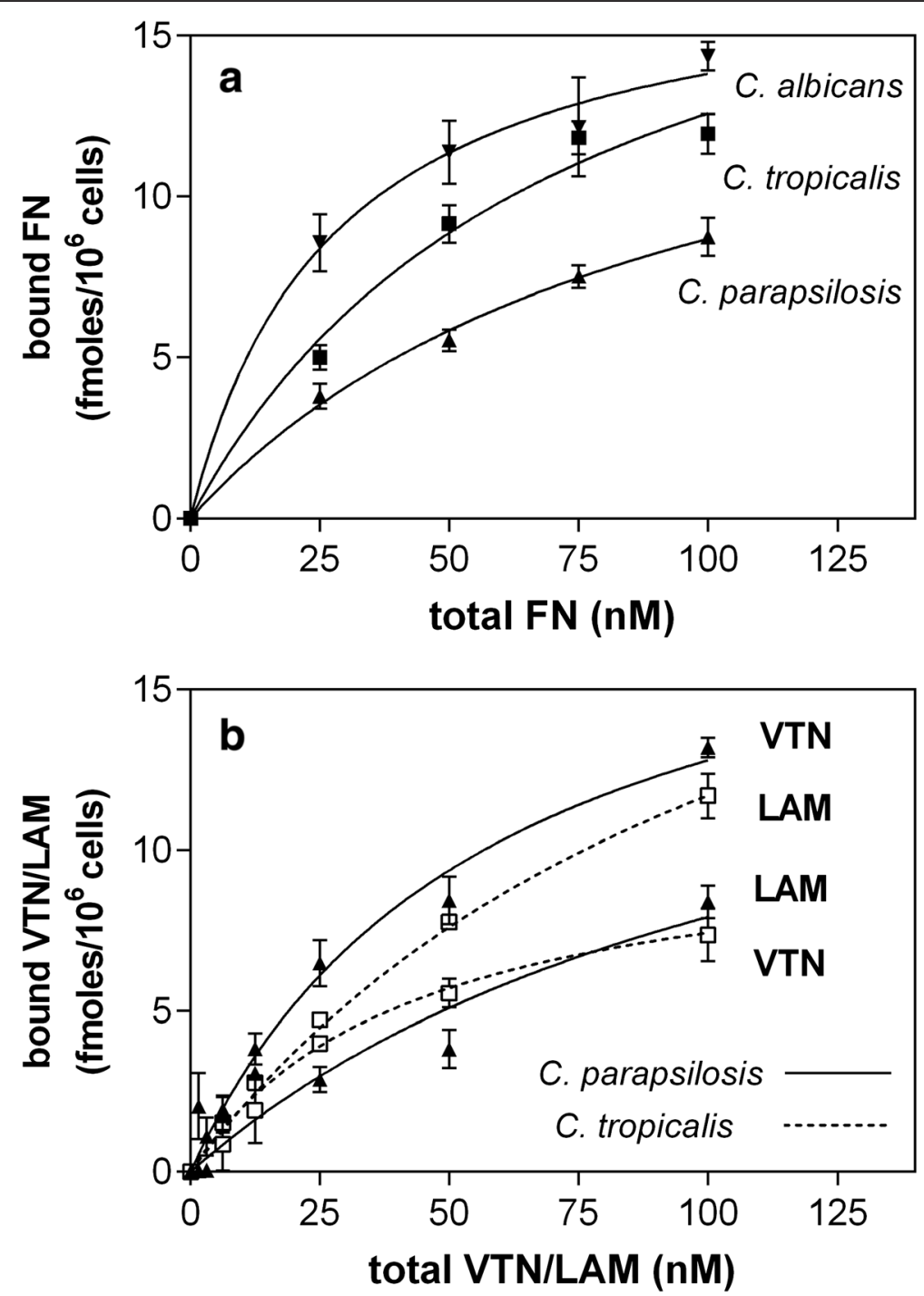

Fig. 1 Binding of extracellular matrix proteins by Candida spp. filamentous forms. a Fibronectin (FN) binding by C. albicans, C. parapsilosis and C. tropicalis; b vitronectin (VTN) and laminin (LAM) binding by C. parapsilosis and C. tropicalis. Filamentous forms obtained from $1 \times 10^{6}$ yeast cells and adsorbed in wells of MaxiSorp microplates were incubated at $37^{\circ} \mathrm{C}$ for $1.5 \mathrm{~h}$ with $50 \mu \mathrm{ll}$ of biotin-labeled FN, VTN or LAM solutions. Additional wells without adsorbed fungal cells but with BSA-blocked surfaces served as controls. The amounts of bound protein were determined using an SA-HRP/TMB system. The readings from control wells were subtracted from the total binding values. Representative binding plots are presented, in which data points represent means from three determinations (three independent wells) \pm standard deviation 
pretreated with: (1) proteinase $\mathrm{K}$, which digests proteins exposed on the surface of fungal cells; (2) $\beta$-1,3-glucanase, which hydrolyzes the $\beta$-1,3-glucan network and also releases a set of $\beta$-1,3-glucan-associated proteins; and (3) a mixture of mannosidases, which degrade the mannan layer of the cell wall. As shown in Fig. 2, the cell wall-associated proteins play a predominant role in ECMP binding in both Candida species investigated. Of other cell wall components, apart from proteins, mannans were additionally found to be important for the binding of fibronectin, as judged from a decrease of the binding level by about $40 \%$ and $20 \%$ for C. parapsilosis and $C$. tropicalis, respectively, after mannosidase treatment. A statistically significant difference between the effect of $\beta$-1,3-glucanase treatment on fibronectin binding in C. parapsilosis and C. tropicalis suggests a lower contribution of $\beta$-1,3-glucan to the interactions of $C$. tropicalis cell wall with this ECMP, relatively to the other species.

Further experiments were thus focused on the proteinaceous components of the fungal cell wall. These were extracted from pseudohyphal forms of the two investigated NAC species and, for comparative purposes, from $C$. albicans hyphae, by a procedure that is postulated to protect the native binding activities toward biological ligands. Therefore, strong denaturants or otherwise harsh conditions could not be applied, which inevitably limited the yield of the protein extraction process. Of the two glucanases used, $\beta$-1,3-glucanase was employed to hydrolyze the entire $\beta-1,3-$ glucan network to release all proteins connected with or embedded in this structure while $\beta$-1,6-glucanase was used to cleave the anchors through which the main adhesins are known to be covalently bound. After these treatments, more than $95 \%$ of the cells remained viable, excluding the possibility of a significant contamination of the obtained protein mixtures with cytoplasmic proteins. The obtained cell wallassociated proteins possessed binding activity toward fibronectin, vitronectin and laminin, as determined using two kinds of binding tests: (1) saturable binding of biotinylated ECMPs (Fig. 3a, b), a test similar to that used for the whole cells and presented in Fig. 1 above; and (2) a competitive test based on the displacement of the biotinylated cell wall-associated proteins from microplate-immobilized fibronectin, vitronectin or laminin by soluble ECMPs (Fig. 3c, d). Notably, the highest displacement (in a range of $50-60 \%$ at 10 -fold molar excess of soluble protein) was observed for fibronectin. Thus, the binding of vitronectin and laminin might be considered to be less "specific", particularly for C. parapsilosis.

\section{Identification of C. parapsilosis and C. tropicalis cell wall-associated proteins that bind fibronectin, vitronectin and laminin}

Subsets of ECMP-binding proteins were isolated from the whole mixtures of cell wall-associated proteins by using two methods: (1) affinity chromatography on agarose beads with immobilized fibronectin, vitronectin and laminin; and (2) fixing, by chemical cross-linking, the protein-protein complexes that were pre-formed in solution. With the first method [24], the mixture of cell wall-associated proteins was incubated with affinity beads and, following removal of the unbound proteins by washing, the mixture was boiled in $2 \%$ SDS to elute adsorbed ECMP-binding fungal proteins and subjected to SDS-PAGE. Only those protein bands that were not visible in the electrophoretic pattern of a control sample, eluted from the gel without immobilized ECMP (instead the reactive groups were blocked with ethanolamine), were further analyzed by nano LC-MS/MS.

With the second method, low-biotinylated fibronectin, vitronectin and laminin were modified in the dark with a bifunctional reagent (sulfo-SDAD) that at one end contains an amine-reactive NHS-ester group. The modified ECMPs were then allowed to interact with the whole mixtures of fungal cell wall-associated proteins. The mixture was then illuminated to activate the second head of the cross-linker, and the covalently fixed ECMP-fungal protein complexes were adsorbed on streptavidin-conjugated beads. The elution of adsorbed proteins was performed by boiling beads in the presence of a reducing agent in order to cleave the disulfide bond localized within the cross-linker arm. This procedure was assumed to release only fungal proteins, and these were further subjected to SDS-PAGE separation and LC-MS/MS analysis. A portion of beads that was incubated with unlabeled fungal proteins that were not subjected to cross-linking but eluted in the same conditions served as a control. As with the first method, only those protein bands that did not appear in the control sample were analyzed.

A list of identified fibronectin-, vitronectin- and lamininbinding fungal proteins, with database accession numbers, protein names, theoretical molecular masses, mass spectrometric analysis parameters and the specifications of the procedures applied, is presented in Table 1.

In C. parapsilosis, 10 fibronectin-binding proteins were found. Half of them were identified with both methods used for the extraction of cell wall-associated proteins. These fibronectin-binding compounds included proteins similar to $C$. albicans elongation factor 2, transketolase, malate synthase, putative amidase and 6-phosphogluconate dehydrogenase. Extraction with $\beta$-1,6-glucanase revealed two proteins (CPAR2_404800 and CPAR2_404780) with $\mathrm{N}$-terminal sequence similarity to the $C$. albicans Als protein family and a protein with similarity to $C$. albicans Rbt1, a protein that is similar to hyphal wall protein 1 (Hwp1). All three proteins are equipped with C-terminal GPI anchors. Additionally, proteins similar to C. albicans glucose-6-phosphate isomerase 

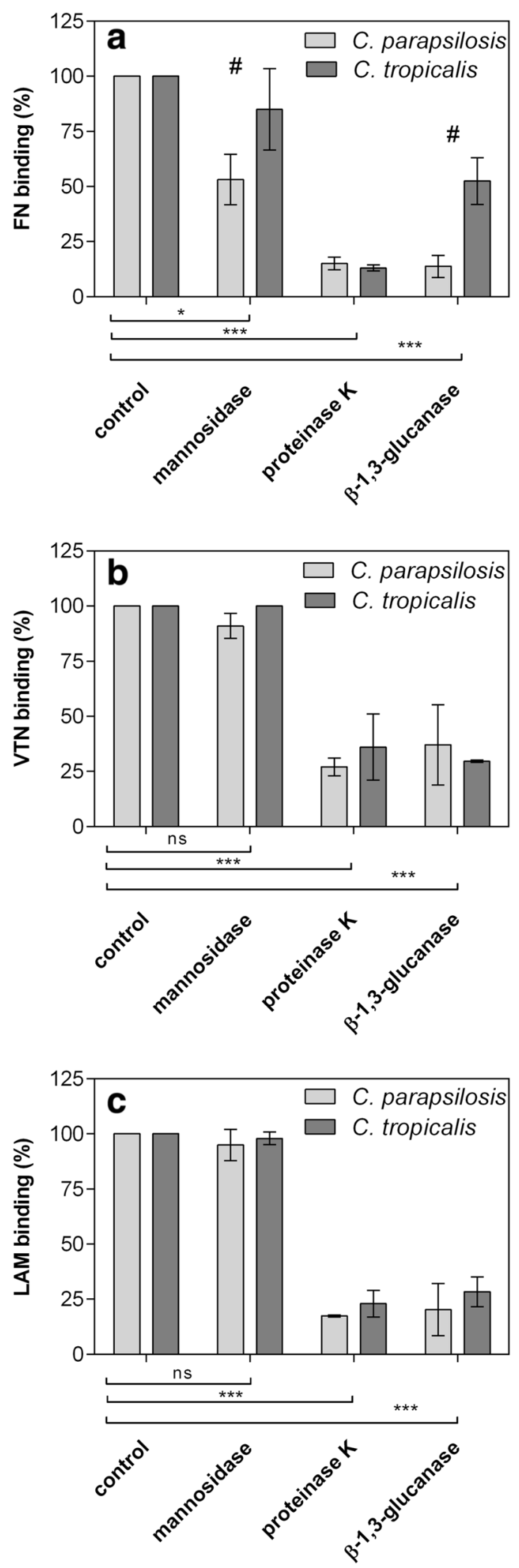

Fig. 2 Involvement of the major C. parapsilosis and C. tropicalis cell wall components in the binding of ECMPs. Binding of biotinylated fibronectin (FN) (a), vitronectin (VTN) (b) and laminin (LAM) (c) was determined for C. parapsilosis and C. tropicalis pseudohyphae (obtained from $5 \times 10^{8}$ yeast cells) that were pretreated with enzymes that digest the major constituents of the fungal cell wall, namely: (1) a mixture of a1-2,3 mannosidase and a1-6 mannosidase; (2) proteinase $\mathrm{K}$; and (3) $\beta$-1,3-glucanase. The cell suspensions were then incubated with $100 \mathrm{nM}$ of each labeled ECMP for $1.5 \mathrm{~h}$ at $37^{\circ} \mathrm{C}$. The amount of bound protein was determined using the SA-HRP/TMB detection system. The binding level of the control (untreated) cells was considered $100 \%$. Bars represent the mean values of three determinations (three independent yeast cultures) \pm standard deviation. Statistical significance levels against the control are indicated with ${ }^{*} p<0.05,{ }^{* * *} p<0.001$ or ns "not significant", whereas statistically significant comparisons between two tested species are marked with \# $(p<0.05)$

and phosphoglycerate mutase were identified as putative $C$. parapsilosis fibronectin-binding proteins. The first was also identified as a vitronectin-binding protein and the second as a laminin-binding protein in C. parapsilosis. Moreover, the other three lamininbinding proteins found, including one protein with an $\mathrm{N}$-terminal similar to that of Als, were the same as those identified during the fibronectin-binding analysis. In a set of putative $C$. parapsilosis vitronectin-binding proteins, except the homolog of $C$. albicans glucose6-phosphate isomerase, other five proteins were also able to bind fibronectin.

In $C$. tropicalis, four proteins, including malate synthase (detected only after the $\beta$-1,6-glucanase extraction), fructose-1,6-bisphosphatase, enolase and transaldolase were common fibronectin, vitronectin and laminin binders. Elongation factor 2 was additionally identified as a laminin- and vitronectin-binding protein, while catalase as a laminin-binding protein. In fibronectin-, vitronectin- and laminin-binding analyses, a putative GPI-anchored protein with $\mathrm{N}$-terminal sequence similarity to $C$. albicans hyphally regulated cell wall protein (Hyr) was identified after extraction from the $C$. tropicalis cell wall with $\beta-1,6$-glucanase.

\section{Discussion}

The ECM is a connective tissue that not only provides a mechanical support for cells nearby but is also involved in their migration, adherence and proliferation. It is composed of glycosaminoglycans, proteoglycans and fibrous proteins [25]. Fibronectin, one of the major proteinaceous components of the ECM, is a large glycoprotein with a molecular mass of about $440 \mathrm{kDa}$. Fibronectin isoforms occur in both plasma and ECM. In the ECM, this protein is responsible for anchoring the cells to the ECM via binding to cell membrane integrins. Vitronectin is a smaller, $75-\mathrm{kDa}$ protein found in plasma that also forms bridges between the cells and the ECM. Laminin-the main component of the ECM basement membrane-also binds to cell surfaces and self-associates to form a flexible network 

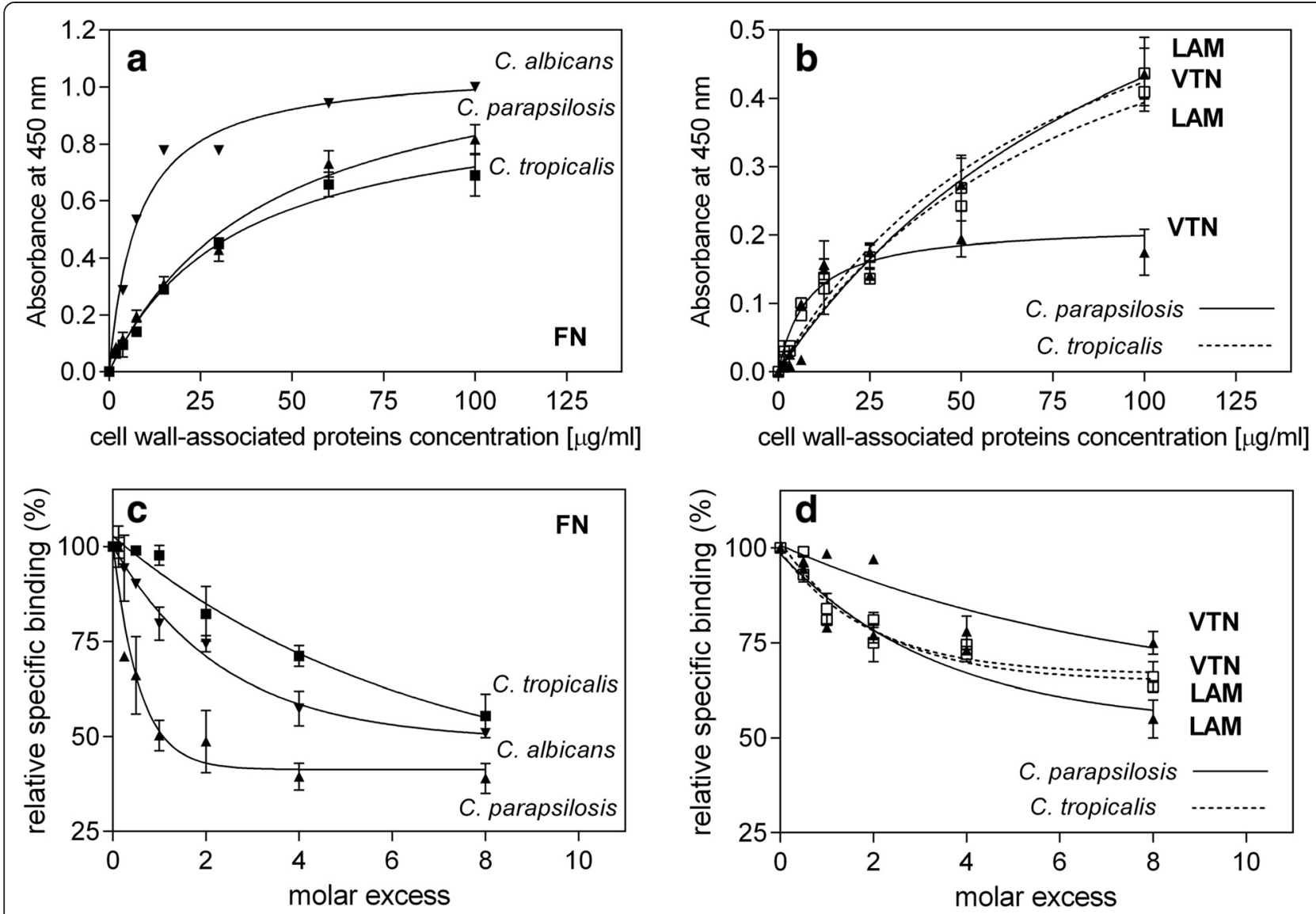

Fig. 3 Interactions of Candida spp. cell wall-associated proteins with fibronectin (FN), vitronectin (VTN) and laminin (LAM). In panels a and $\mathbf{b}$, the plots are presented for saturable binding of biotinylated cell wall-associated proteins extracted from filamentous forms of C. albicans, C. parapsilosis and C. tropicalis to immobilized FN (a) and of cell wall-associated proteins of C. parapsilosis and C. tropicalis to immobilized VTN and LAM (b) (5 pmoles of FN, VTN or LAM adsorbed into wells of MaxiSorp microplates with the unoccupied surfaces blocked with BSA). Panels $\mathbf{c}$ and $\mathbf{d}$ show the respective plots for the displacement of biotinylated cell wall-associated proteins $(40 \mu \mathrm{g} / \mathrm{ml}$ for FN binding or $15 \mu \mathrm{g} / \mathrm{ml}$ for VTN and LAM binding) from microplate-immobilized ECMPs (3 pmoles of FN or 1.25 pmoles of VTN or LAM per well) by soluble FN, VTN and LAM added at increasing concentrations. Wells without immobilized ECMPs but coated with BSA served as controls and the values obtained for those wells were subtracted from the total binding values. Results from representative experiments are presented, in which data points represent mean values from three determinations (three wells) \pm standard deviation

that provides a scaffold for the cell layer. The RGD domains (named after their critical three-amino acid sequence of Arg-Gly-Asp) are crucial for the interaction of fibronectin, vitronectin and laminin with cells [26]. All of these three proteins can interact with other components of the ECM to enhance its stability, elasticity and strength [25]. For bacteria and other pathogenic microorganisms, adhesion to the ECM and human host cells is a critical step in the first stage of infection [15]. This phenomenon is also essential for development of the commensal status of microbes-such as the Candida yeasts-that belong to the physiological microbiota of humans.

The strong binding of fibronectin, laminin and vitronectin by $C$. albicans cells involves multiple cell wall proteins $[16-18,27]$. Fibronectin- and laminin-binding by $C$. tropicalis has also been reported [20], albeit without deeper insight into this phenomenon. Significantly, the adhesion of these two ECMPs to C. tropicalis cells was significantly higher than to C. albicans [28]. In our current analyses, for the first time, the $C$. parapsilosis and C. tropicalis cell wall-associated proteins were characterized in terms of interactions with fibronectin, vitronectin and laminin. These two NAC species are characterized by high adhesiveness and an ability to form biofilm and are currently emerging fungal pathogens with increasing rates of morbidity and mortality [2, 29].

The candidal cell wall is composed of proteins, chitin, $\beta$-1,3-glucan and $\beta$-1,6-glucan, mannans and small amounts of lipids [30,31]. Our studies indicated that cell wall-associated proteins are crucial to the binding of fibronectin, vitronectin and laminin by $C$. parapsilosis and $C$. tropicalis pseudohyphae, although a smaller contribution 
Table 1 Mass spectrometric identification of fibronectin-, vitronectin- and laminin-binding C. parapsilosis and C. tropicalis cell wall-associated proteins

\begin{tabular}{|c|c|c|c|c|c|c|c|c|c|}
\hline \multicolumn{10}{|l|}{ C. parapsilosis } \\
\hline \multirow{2}{*}{$\begin{array}{l}\text { NCBI protein database } \\
\text { accession number }\end{array}$} & \multirow[t]{2}{*}{ Protein } & \multirow{2}{*}{$\begin{array}{l}\text { Molecular } \\
\text { mass }[\mathrm{kDa}]\end{array}$} & \multirow[t]{2}{*}{ Scores } & \multirow{2}{*}{$\begin{array}{l}\text { Number of } \\
\text { peptides }\end{array}$} & \multirow{2}{*}{$\begin{array}{l}\text { Sequence } \\
\text { coverage } \\
{[\%]}\end{array}$} & \multicolumn{2}{|c|}{ Method of extraction from fungal cell wall } & \multicolumn{2}{|c|}{ Method of identification } \\
\hline & & & & & & $\beta$-1,3-glucanase & $\beta$-1,6-glucanase & AFC & $\mathrm{CL}$ \\
\hline \multicolumn{10}{|c|}{ Fibronectin-binding proteins } \\
\hline gi|354547941 & $\begin{array}{l}\text { hypothetical protein CPAR2_404800 } \\
\text { [C. parapsilosis], cell wall agglutinin, } \\
\text { N-terminal, ligand sugar binding }\end{array}$ & 143.6 & 736 & 13 & 14 & & + & + & \\
\hline gi|354547939 & $\begin{array}{l}\text { hypothetical protein CPAR2_404780 } \\
\text { [C. parapsilosis], cell wall agglutinin, } \\
\text { N-terminal, ligand sugar binding }\end{array}$ & 113.6 & 525 & 10 & 13 & & + & + & \\
\hline gi|354546787 & $\begin{array}{l}\text { hypothetical protein CPAR2_211630 } \\
\text { [C. parapsilosis], similar to C. albicans } \\
\text { Eft2, elongation factor } 2\end{array}$ & 93.8 & 259 & 11 & 14 & + & + & + & + \\
\hline gi|354547813 & $\begin{array}{l}\text { hypothetical protein CPAR2_403510 } \\
\text { [C. parapsilosis], similar to C. albicans } \\
\text { Rbt1, cell wall protein with similarity } \\
\text { to Hwp1, required for virulence }\end{array}$ & 83.8 & 73 & 2 & 1 & & + & & + \\
\hline gi|354545198 & $\begin{array}{l}\text { hypothetical protein CPAR2_804740 } \\
\text { [C.parapsilosis], similar to C. albicans } \\
\text { Tkl1, putative transketolase }\end{array}$ & 74.6 & 166 & 6 & 8 & + & + & + & + \\
\hline gi|354545113 & $\begin{array}{l}\text { hypothetical protein CPAR2_803890 } \\
\text { [C. parapsilosis], similar to C. albicans } \\
\text { Mls1, malate synthase }\end{array}$ & 62.7 & 1434 & 32 & 72 & + & + & + & + \\
\hline gi|354544475 & $\begin{array}{l}\text { hypothetical protein CPAR2_301880 } \\
\text { [C. parapsilosis], putative amidase }\end{array}$ & 61.7 & 938 & 18 & 38 & + & + & + & + \\
\hline gi|354546116 & $\begin{array}{l}\text { hypothetical protein CPAR2_204880 } \\
\text { [C. parapsilosis], similar to C. albicans Pgi1, } \\
\text { putative glucose-6-phosphate isomerase }\end{array}$ & 61.5 & 104 & 3 & 7 & & + & + & \\
\hline gi|354545980 & $\begin{array}{l}\text { hypothetical protein CPAR2_203520 } \\
\text { [C. parapsilosis], similar to C. albicans Gnd1, } \\
\text { putative 6-phosphogluconate dehydrogenase }\end{array}$ & 55.4 & 184 & 5 & 15 & + & + & & + \\
\hline gi|354546805 & $\begin{array}{l}\text { hypothetical protein CPAR2_211810 } \\
\text { [C. parapsilosis], similar to C. albicans } \\
\text { Gpm1, phosphoglycerate mutase }\end{array}$ & 27.6 & 366 & 13 & 33 & & + & & + \\
\hline \multicolumn{10}{|c|}{ Vitronectin-binding proteins } \\
\hline gi|8927048 & elongation factor 2 [C. parapsilosis] & 90.3 & 362 & 8 & 10 & + & + & + & + \\
\hline gi|354545198 & $\begin{array}{l}\text { hypothetical protein CPAR2_804740 } \\
\text { [C. parapsilosis], similar to C. albicans } \\
\text { Tkl1, putative transketolase }\end{array}$ & 74.6 & 146 & 3 & 4 & + & + & + & + \\
\hline
\end{tabular}


Table 1 Mass spectrometric identification of fibronectin-, vitronectin- and laminin-binding C. parapsilosis and C. tropicalis cell wall-associated proteins (Continued)

\begin{tabular}{|c|c|c|c|c|c|c|c|c|c|}
\hline gi|354545113 & $\begin{array}{l}\text { hypothetical protein CPAR2_803890 } \\
\text { [C. parapsilosis], similar to C. albicans } \\
\text { Mls1, malate synthase }\end{array}$ & 62.7 & 927 & 19 & 43 & & + & + & + \\
\hline gi|354544475 & $\begin{array}{l}\text { hypothetical protein CPAR2_301880 } \\
\text { [C. parapsilosis], putative amidase }\end{array}$ & 62.1 & 1452 & 25 & 45 & + & + & + & + \\
\hline gi|354546116 & $\begin{array}{l}\text { hypothetical protein CPAR2_204880 } \\
\text { [C. parapsilosis], similar to C. albicans Pgi1, } \\
\text { putative glucose-6-phosphate isomerase }\end{array}$ & 61.5 & 655 & 15 & 22 & & + & + & \\
\hline gi|354545980 & $\begin{array}{l}\text { hypothetical protein CPAR2_203520 } \\
\text { [C. parapsilosis], similar to C. albicans Gnd1, } \\
\text { putative 6-phosphogluconate dehydrogenase }\end{array}$ & 55.4 & 636 & 14 & 31 & + & + & + & + \\
\hline gi|354546348 & $\begin{array}{l}\text { hypothetical protein CPAR2_207210 } \\
\text { [C. parapsilosis], similar to C. albicans } \\
\text { Eno1, enolase }\end{array}$ & 47 & 229 & 4 & 13 & & + & + & \\
\hline gi|354545888 & $\begin{array}{l}\text { hypothetical protein CPAR2_202600 } \\
\text { [C. parapsilosis], similar to C. albicans Tal1, } \\
\text { putative transaldolase }\end{array}$ & 35.7 & 526 & 10 & 36 & & + & + & \\
\hline \multicolumn{10}{|c|}{ Laminin-binding proteins } \\
\hline gi|354547939 & $\begin{array}{l}\text { hypothetical protein CPAR2_404780 } \\
\text { [C. parapsilosis], cell wall agglutinin, } \\
\text { N-terminal, ligand sugar binding }\end{array}$ & 113.6 & 93 & 3 & 2 & & + & + & \\
\hline gi|354545113 & $\begin{array}{l}\text { hypothetical protein CPAR2_803890 } \\
\text { [C. parapsilosis], similar to C. albicans } \\
\text { Mls1, malate synthase }\end{array}$ & 62.7 & 425 & 9 & 20 & & + & & + \\
\hline gi|354544475 & $\begin{array}{l}\text { hypothetical protein CPAR2_301880 } \\
\text { [C. parapsilosis], putative amidase }\end{array}$ & 61.7 & 1629 & 67 & 58 & + & + & & + \\
\hline gi|354546805 & $\begin{array}{l}\text { hypothetical protein CPAR2_211810 } \\
\text { [C. parapsilosis], similar to C. albicans } \\
\text { Gpm1, phosphoglycerate mutase }\end{array}$ & 27.3 & 167 & 4 & 18 & + & & & + \\
\hline \multicolumn{10}{|c|}{ Fibronectin-binding proteins } \\
\hline gi|255722852 & $\begin{array}{l}\text { predicted protein [C. tropicalis MYA-3404], } \\
\text { hyphally regulated cell wall protein, N-terminal }\end{array}$ & 194.6 & 202 & 6 & 4 & & + & + & \\
\hline gi|255728333 & malate synthase [C. tropicalis MYA-3404] & 62.4 & 921 & 23 & 58 & & + & + & + \\
\hline gi|255727881 & enolase 1 [C. tropicalis MYA-3404] & 46.9 & 619 & 33 & 55 & & + & + & + \\
\hline gi|255732698 & $\begin{array}{l}\text { fructose-1,6-bisphosphatase [C. tropicalis } \\
\text { MYA-3404] }\end{array}$ & 40.5 & 134 & 4 & 14 & + & + & + & + \\
\hline gi|255722021 & transaldolase [C. tropicalis MYA-3404] & 35.5 & 123 & 3 & 8 & & + & + & \\
\hline \multicolumn{10}{|c|}{ Vitronectin-binding proteins } \\
\hline gi|255722852 & $\begin{array}{l}\text { predicted protein [C. tropicalis MYA-3404], } \\
\text { hyphally regulated cell wall protein, N-terminal }\end{array}$ & 194.6 & 107 & 3 & 2 & & + & + & \\
\hline
\end{tabular}


Table 1 Mass spectrometric identification of fibronectin-, vitronectin- and laminin-binding C. parapsilosis and C. tropicalis cell wall-associated proteins (Continued)

\begin{tabular}{|c|c|c|c|c|c|c|c|c|c|}
\hline gi|240134900 & elongation factor 2 [Candida tropicalis MYA-3404] & 90.2 & 378 & 10 & 11 & & + & + & \\
\hline gi|255728333 & malate synthase [C. tropicalis MYA-3404] & 62.4 & 529 & 12 & 25 & & + & & + \\
\hline gi|255727881 & enolase 1 [C. tropicalis MYA-3404] & 46.9 & 157 & 5 & 18 & + & & + & \\
\hline gi|255732698 & fructose-1,6-bisphosphatase [C. tropicalis MYA-3404] & 40.5 & 320 & 7 & 25 & + & + & + & + \\
\hline gi|255722021 & transaldolase [C. tropicalis MYA-3404] & 35.5 & 513 & 10 & 28 & & + & & + \\
\hline \multicolumn{10}{|c|}{ Laminin-binding proteins } \\
\hline gi|255722852 & $\begin{array}{l}\text { predicted protein [C. tropicalis MYA-3404], } \\
\text { hyphally regulated cell wall protein, N-terminal }\end{array}$ & 194.6 & 103 & 2 & 1 & & + & + & \\
\hline gi|240134900 & elongation factor 2 [Candida tropicalis MYA-3404] & 90.2 & 259 & 7 & 8 & & + & + & \\
\hline gi|255728333 & malate synthase [C. tropicalis MYA-3404] & 62.4 & 337 & 10 & 22 & & + & + & + \\
\hline gi|240132975 & peroxisomal catalase [Candida tropicalis MYA-3404] & 55.1 & 104 & 3 & 5 & & + & + & \\
\hline gi|255727881 & enolase 1 [C. tropicalis MYA-3404] & 46.9 & 189 & 4 & 12 & & + & + & \\
\hline gi|255732698 & fructose-1,6-bisphosphatase [C. tropicalis MYA-3404] & 40.5 & 136 & 4 & 15 & + & & + & \\
\hline gi|255722021 & transaldolase [C. tropicalis MYA-3404] & 35.5 & 487 & 12 & 44 & & + & + & \\
\hline
\end{tabular}

Cell wall-associated proteins were extracted from C. parapsilosis and C. tropicalis pseudohyphae, using either $\beta$-1,3-glucanase (+ $\beta$-mercaptoethanol) or $\beta$-1,6-glucanase. Subsets of ECMP-binding proteins were isolated from the whole cell wall protein mixtures, using affinity chromatography (AFC) or cross-linking (CL) methods. After SDS-PAGE electrophoresis, specific protein bands were excised and digested using trypsin. Peptides were analyzed using the UltiMate 3000 RSLCnano System coupled to a micrOTOF-QII mass spectrometer and Apollo Source ESI nano-sprayer (for AFC-isolated proteins) or an Dionex UItimate 3000 UHPLC system coupled to an HCT Ultra ETDII mass spectrometer equipped with an ESI ion source (for CL-isolated proteins). The obtained lists of peaks were searched against the NCBI protein database using an in-house Mascot server. The data represent a combination of results obtained for the extracts of cell wall-associated proteins, prepared from three independent yeast cultures. For a given extraction method ( $\beta$-1,3-glucanase vs. $\beta$-1,6-glucanase) and ECMP-binder isolation method (AFC vs. CL), only those proteins are listed that were found on the analysis of all three yeast cultures. Hence, each " + " sign means that a given protein was found at least three times. The best Mascot parameters (scores, number of identified peptides and sequence coverage) ever recorded for a given protein are specified; the proteins identified with a score $>70$ and a number of identified peptides $\geq 2$ are only listed 
from polysaccharides cannot be excluded. Complementary data were previously presented for C. albicans [32, 33], considered to be the most adhesive and accordingly also the most pathogenic species of the genus Candida $[34,35]$. Our current observation that the adhesive abilities of two investigated NAC species toward ECMPs were comparable to those of $C$. albicans suggests an important role of this particular virulence attribute in the pathogenesis of infections caused by C. tropicalis and C. parapsilosis.

The protein mixtures, extracted from the fungal cell wall with the use of $\beta$-1,3-glucanase and $\beta$-1,6-glucanase, were confirmed to possess high fibronectin-, vitronectin- and laminin-binding activity. Hence, the cell wall-associated ECMP-binding components underwent the isolation by affinity chromatography and chemical cross-linking, and were further identified by mass spectrometry. The results obtained by these two different identification methods and presented in Table 1 seemed to be complementary and indicated proteins with distinct affinities for fibronectin-, vitronectin- or laminin as well as some that shared an ability to bind two or three ECMPs. For comparative purposes, a list of ECMP-binding proteins, unequivocally identified in C. albicans in the numerous previous studies, is presented in Table 2, and will be used in the further discussion below.

As in C. albicans, the fibronectin-, vitronectin- and laminin-binding proteins of C. parapsilosis and C. tropicalis belong to two groups: (1) true cell wall components similar to typical C. albicans adhesins; and (2) atypical, cytoplasm-derived but surface-exposed proteins, sometimes collectively termed "moonlighting proteins" [36]. Evidence suggests that gene families coding for specialized adhesins in C. albicans also exist in the C. parapsilosis and C. tropicalis genome [19] but to date their protein products have not been characterized in detail at the molecular or functional level [37]. In our current study, at least two putative representatives of the Als-like protein family and a putative homolog of $C$. albicans Rbt1 protein from the Hwp family were found to possess the ability to bind

Table 2 Candida albicans proteins with the previously confirmed binding affinity to human fibronectin, vitronectin and laminin

\begin{tabular}{|c|c|c|c|}
\hline Abbreviation & Protein name & Method used for protein identification and confirmation of binding to ECMPs & Reference \\
\hline \multicolumn{4}{|c|}{ Fibronectin-binding proteins } \\
\hline \multirow[t]{3}{*}{ Als1 } & Agglutinin-like sequence protein 1 & $\begin{array}{l}\text { expression in Saccharomyces cerevisiae followed by binding to magnetic beads } \\
\text { coated with fibronectin }\end{array}$ & [38] \\
\hline & & expression in S. cerevisiae followed by binding to microplate-immobilized fibronectin & [16] \\
\hline & & $\begin{array}{l}\text { expression of the Als } 1 \mathrm{~N} \text {-terminal part in } \mathrm{S} \text {. cerevisiae followed by its purification and } \\
\text { surface plasmon resonance measurements }\end{array}$ & [39] \\
\hline \multirow[t]{2}{*}{ Als3 } & Agglutinin-like sequence protein 3 & expression in S. cerevisiae followed by binding to microplate-immobilized fibronectin & [16] \\
\hline & & expression in S. cerevisiae followed by microtiter plate-based assay & [40] \\
\hline \multirow[t]{2}{*}{ Als5 } & Agglutinin-like sequence protein 5 & expression in S. cerevisiae followed by binding to microplate-immobilized fibronectin & [16] \\
\hline & & $\begin{array}{l}\text { binding of protein fragments-Als5 1-431 and Als5 1-664-to fibronectin-coated } \\
\text { microtiter plate wells }\end{array}$ & [41] \\
\hline Hwp1 & Hyphal cell wall protein 1 & expression in S. cerevisiae followed by microtiter plate-based assay & [40] \\
\hline Tdh3 & $\begin{array}{l}\text { Glyceraldedyhde-3-phosphate } \\
\text { dehydrogenase }\end{array}$ & immunoaffinity purification of Tdh3 followed by ligand Western Blot assay & [18] \\
\hline Adh1 & Alcohol dehydrogenase & $\begin{array}{l}\text { screening of C. albicans cDNA library with polyclonal antibodies against receptor } \\
\text { for fibronectin }\end{array}$ & [17] \\
\hline \multicolumn{4}{|c|}{ Vitronectin-binding proteins } \\
\hline Adh1 & Alcohol dehydrogenase & $\begin{array}{l}\text { screening of C. albicans cDNA library with polyclonal antibodies against receptor } \\
\text { for vitronectin }\end{array}$ & [17] \\
\hline Gpm1 & Phosphoglycerate mutase & $\begin{array}{l}\text { enzyme-linked ligand sorbent assay (ELISA) with microplate-immobilized recombinant } \\
\text { Gpm1 }\end{array}$ & [45] \\
\hline \multicolumn{4}{|c|}{ Laminin-binding proteins } \\
\hline \multirow[t]{3}{*}{ Als1 } & Agglutinin-like sequence protein 1 & expression in S. cerevisiae followed by binding to magnetic beads coated with laminin & [38] \\
\hline & & expression in S. cerevisiae followed by binding to microplate-immobilized laminin & [16] \\
\hline & & $\begin{array}{l}\text { expression of the Als1 } \mathrm{N} \text {-terminal part in S. cerevisiae followed by its purification and surface } \\
\text { plasmon resonance measurements }\end{array}$ & {$[39]$} \\
\hline Als3 & Agglutinin-like sequence protein 3 & expression in S. cerevisiae followed by binding to microplate-immobilized laminin & [16] \\
\hline Als5 & Agglutinin-like sequence protein 5 & expression in S. cerevisiae followed by binding to microplate-immobilized laminin & [16] \\
\hline Tdh3 & $\begin{array}{l}\text { Glyceraldedyhde-3-phosphate } \\
\text { dehydrogenase }\end{array}$ & immunoaffinity purification of Tdh3 followed by ligand Western Blot assay & {$[18]$} \\
\hline
\end{tabular}


ECMPs in C. parapsilosis. In C. albicans (Table 2) three representatives of Als-like protein family-Als1, Als3 and Als5-were indicated as proteins capable of fibronectin and laminin binding and, additionally, also Hwp1 was found to be a fibronectin-binding protein [16, 38-41]. In C. tropicalis, an ECMP-binding protein with high sequence similarity to members of $C$. albicans adhesins from the Iff/Hyr (hyphally regulated) protein family was identified. The C. albicans homologs of adhesive proteins are expected to mainly be covalently attached to the layer of $\beta-1,6$-glucans through their GPI anchor, or, as in the case of some members of the Iff family, might be bound by alkali-labile and disulfide bonds to the glucan network or other cell wall proteins $[37,42,43]$.

Moreover, several atypical proteins that are probably more loosely attached to the C. parapsilosis and C. tropicalis cell wall were identified as putative ECMP binding partners. Involvement of some of these "moonlighting" proteins, such as enolase, phosphogluconate mutase, elongation factor 2 and 6-phosphogluconate dehydrogenase, in ECMP binding is additionally supported by previous reports that their homologs, present in the $C$. albicans cell wall, were able to bind the human high-molecular weight kininogen [24] and that the homologs of the first two "moonlighting" proteins had an affinity to human plasminogen [44]. Additionally, phosphogluconate mutase was indicated as $C$. albicans cell surface-exposed protein involved in interactions with vitronectin [45]. Moreover, recent studies of surface antigens of NAC species indicated that both $C$. parapsilosis and C. tropicalis possess cell wall-associated enolases capable of triggering the host immune response during fungal infection $[46,47]$. Thus, they are likely to play a role in other pathogenicityassociated processes, such as adhesion to host cells and proteins [36]. It should also be emphasized that enolase is a confirmed cell surface-exposed plasminogen-binding protein in many different organisms [48].

In case of C. albicans, two further atypical proteins were found as ECMP-binding proteins, namely alcohol dehydrogenase [17] and glyceraldehyde-3-phosphate dehydrogenase [18]. Neither was identified as engaged in ECMP-binding phenomenon for the NAC species investigated in our current study.

In our current study of C. parapsilosis and C. tropicalis, malate synthase was also identified as a fibronectin, vitronectin and laminin binder. Interestingly, in another fungal pathogen, Paracoccidioides brasiliensis, this enzyme was shown to be exposed at the cell surface and to bind fibronectin, collagen type I and collagen type IV, and to also be responsible for adhesion of the fungus to pulmonary epithelial cells [49].

The above comparisons between three Candida species indicate that C. albicans and C. parapsilosis share some similar ECMP-binding proteins such as Als-like proteins, a protein similar to Hwp1 and phosphogluconate mutase. However, even for those two species additional proteins were identified, possibly accounting for slight differences in the ECMP-binding levels observed in this study. Interestingly, the comparisons between $C$. tropicalis and $C$. albicans ECMP-binding proteins, despite a similar adhesiveness of these two species, did not indicate any common ECMP binders. These differences can be taken into consideration to propose in the future some new strategies to reduce the ECM-binding ability of C. tropicalis that seems to rely on other molecules than those used by C. albicans. Such an approach might be useful for both a diversification and an extension of currently used therapeutic strategies, especially those based on the inhibition of the fungus interactions with host proteins and tissues.

\section{Conclusions}

The results of our present study are both extensive and consistent, due to the use of two methods to extract the fungal cell wall-associated proteins and two methods (affinity chromatography and cross-linking) to qualify the ECMP-binding activity. Further detailed analysis will probably confirm the roles of individual proteins in ECMfungal cell interactions. The collective action of all of the above-mentioned fungal ECMP binders should greatly enhance the ability of C. parapsilosis and C. tropicalis to adhere to the ECM and facilitate the invasion of human hosts. Detailed characteristics of this molecular pathogenicity mechanism for the investigated NAC species could add to the development of new methods for treating severe infection caused by these emerging pathogens.

\section{Abbreviations}

AFC: affinity chromatography; BSA: bovine serum albumin; CL: cross-linking; DTT: dithiothreitol; ECM: extracellular matrix; ECMP: extracellular matrix protein; ESI: electrospray ionization; FN: fibronectin; LAM: Iaminin; LC: liquid chromatography; LC-MS/MS: liquid chromatography-coupled tandem mass spectrometry; MS: mass spectrometry; MS/MS: tandem mass spectrometry; NAC: non-albicans Candida species; SA-HRP: horseradish peroxidase-conjugated streptavidin; SDS: sodium dodecyl sulphate; SDS-PAGE: sodium dodecyl sulphate polyacrylamide gel electrophoresis; sulfo-SDAD: sulfosuccinimidyl 2-([4,4'-azipentanamido]ethyl)-1,3'-dithiopropionate; PBS: phosphate-buffered saline; UHPLC: ultrahigh-pressure liquid chromatography; VTN: vitronectin.

\section{Competing interests}

The authors declare that they have no competing interests.

\section{Authors' contributions}

AK conceived the study, coordinated the experimental work, interpreted the data and edited the final manuscript version. JKK performed the affinity

chromatography experiments and cross-linking assays, wrote the first manuscript draft and contributed to the further steps of manuscript edition. DZ cultured yeast cells, extracted fungal cell wall-associated proteins, carried out their biochemical characterization and performed the ECMP-binding assays. OB conducted the LC-MS/MS analyses with the use of HCT Ultra ion-trap mass spectrometer. SKK and UJ performed the nano-LC-MS/MS analyses with the use of a micrOTOF-Q\|I spectrometer. MRK helped in data interpretation and contributed to manuscript writing and editing. All authors read and approved the final manuscript.

Authors' information

Not applicable. 


\section{Availability of data and materials}

All data sets on which the conclusions of this article rely are presented in the main paper. The raw data are available to any scientist who wishes to use them for non-commercial purposes and can be obtained from the corresponding author on request.

\section{Acknowledgments}

This work was supported in part by the National Science Centre of Poland (grant no. 2012/07/B/NZ1/02867 awarded to A.K.). MS measurements were performed using a micrOTOF spectrometer that was purchased by the European Regional Development Fund as part of the Polish Innovation Economy Operational Program (contract no. POIG.02.01.00-12-167/08, project Małopolska Center of Biotechnology). The Faculty of Biochemistry, Biophysics and Biotechnology of the Jagiellonian University in Krakow, Poland is a beneficiary of structural funds from the European Union (grant no. POIG.02.01.00-12-064/08: "Molecular biotechnology for health") and a partner of the Leading National Research Center (KNOW) supported by the Ministry of Science and Higher Education, Poland.

\section{Author details}

${ }^{1}$ Department of Analytical Biochemistry, Faculty of Biochemistry, Biophysics and Biotechnology, Jagiellonian University in Krakow, Gronostajowa 7, 30-387 Krakow, Poland. ${ }^{2}$ Department of Physical Biochemistry, Faculty of Biochemistry, Biophysics and Biotechnology, Jagiellonian University in Krakow, Gronostajowa 7, 30-387 Krakow, Poland. ${ }^{3}$ Department of Structural Biology, Malopolska Centre of Biotechnology, Jagiellonian University in Krakow, Gronostajowa 7, 30-387 Krakow, Poland.

\section{Received: 29 April 2015 Accepted: 25 September 2015 Published online: 05 October 2015}

\section{References}

1. Sganga G, Bianco G, Frongillo F, Lirosi MC, Nure E, Agnes S. Fungal infections after liver transplantation: incidence and outcome. Transplant Proc. 2014;46(7):2314-8.

2. Sardi JC, Scorzoni L, Bernardi T, Fusco-Almeida AM, Mendes Giannini MJ. Candida species: current epidemiology, pathogenicity, biofilm formation, natural antifungal products and new therapeutic options. J Med Microbiol. 2013;62(Pt1):10-24.

3. Nagao M, Hotta G, Yamamoto M, Matsumura Y, Ito Y, Takakura S, et al. Predictors of Candida spp. as causative agents of catheter-related bloodstream infections. Diagn Microbiol Infect Dis. 2014;80(3):200-3.

4. Tang HJ, Liu WL, Lin HL, Lai CC. Epidemiology and prognostic factors of candidemia in cancer patients. PLoS One. 2014;9(6):e99103.

5. Trofa D, Gácser A, Nosanchuk JD. Candida parapsilosis, an emerging fungal pathogen. Clin Microbiol Rev. 2008;21(4):606-25.

6. Tang HJ, Liu WL, Lin HL, Lai CC. Epidemiology and prognostic factors of candidemia in elderly patients. Geriatr Gerontol Int. 2015;15(6):688-93.

7. Horn DL, Neofytos D, Anaissie EJ, Fishman JA, Steinbach WJ, Olyaei AJ, et al. Epidemiology and outcomes of candidemia in 2019 patients: data from the prospective antifungal therapy alliance registry. Clin Infect Dis. 2009;48(12):1695-703.

8. Ortega M, Marco F, Soriano A, Almela M, Martínez JA, López J, et al. Candida species bloodstream infection: epidemiology and outcome in a single institution from 1991 to 2008. J Hosp Infect. 2011;77(2):157-61.

9. Singh R, Parija SC. Candida parapsilosis: an emerging fungal pathogen. Indian J Med Res. 2012;136(4):671-3.

10. Arendrup MC. Candida and candidaemia. Susceptibility and epidemiology. Dan Med J. 2013;60(11):B4698.

11. Wisplinghoff H, Ebbers J, Geurtz L, Stefanik D, Major $Y$, Edmond MB, et al. Nosocomial bloodstream infections due to Candida spp. in the USA: species distribution, clinical features and antifungal susceptibilities. Int J Antimicrob Agents. 2014;43(1):78-81

12. Pfaller M, Neofytos D, Diekema D, Azie N, Meier-Kriesche HU, Quan SP, et al. Epidemiology and outcomes of candidemia in 3648 patients: data from the Prospective Antifungal Therapy (PATH Alliance ${ }^{\circledast}$ ) registry, 2004-2008. Diagn Microbiol Infect Dis. 2012;74(4):323-31.

13. Bendel CM, Hostetter MK. Distinct mechanisms of epithelial adhesion for Candida albicans and Candida tropicalis. Identification of the participating ligands and development of inhibitory peptides. J Clin Invest. 1993;92(4):1840-9.
14. Brunke S, Hube B. Two unlike cousins: Candida albicans and C. glabrata infection strategies. Cell Microbiol. 2013;15(5):701-8.

15. Chagnot C, Listrat A, Astruc T, Desvaux M. Bacterial adhesion to animal tissues: protein determinants for recognition of extracellular matrix components. Cell Microbiol. 2012;14(11):1687-96.

16. Sheppard DC, Yeaman MR, Welch WH, Phan QT, Fu Y, Ibrahim AS, et al. Functional and structural diversity in the Als protein family of Candida albicans. J Biol Chem. 2004;279(29):30480-9.

17. Klotz SA, Pendrak ML, Hein RC. Antibodies to alpha5beta1 and alpha(v)beta3 integrins react with Candida albicans alcohol dehydrogenase. Microbiology. 2001;147(Pt11):3159-64.

18. Gozalbo D, Gil-Navarro I, Azorín I, Renau-Piqueras J, Martínez JP, Gil ML. The cell wall-associated glyceraldehyde-3-phosphate dehydrogenase of Candida albicans is also a fibronectin and laminin binding protein. Infect Immun. 1998;66(5):2052-9.

19. Butler G, Rasmussen MD, Lin MF, Santos MA, Sakthikumar S, Munro CA, et al. Evolution of pathogenicity and sexual reproduction in eight Candida genomes. Nature. 2009;459(7247):657-62.

20. DeMuri GP, Hostetter MK. Evidence for a beta 1 integrin fibronectin receptor in Candida tropicalis. J Infect Dis. 1996;174(1):127-32.

21. Bradford MM. A rapid and sensitive method for the quantitation of microgram quantities of protein utilizing the principle of protein-dye binding. Anal Biochem. 1976;72:248-54.

22. Laemmli UK. Cleavage of structural proteins during the assembly of the head of bacteriophage T4. Nature. 1970;227(5259):680-5.

23. Rapala-Kozik M, Karkowska J, Jacher A, Golda A, Barbasz A, Guevara-Lora I, et al. Kininogen adsorption to the cell surface of Candida spp. Int Immunopharmacol. 2008:8(2):237-41.

24. Karkowska-Kuleta J, Kedracka-Krok S, Rapala-Kozik M, Kamysz W, Bielinska S, Karafova A, et al. Molecular determinants of the interaction between human high molecular weight kininogen and Candida albicans cell wall: Identification of kininogen-binding proteins on fungal cell wall and mapping the cell wall-binding regions on kininogen molecule. Peptides. 2011;32(12):2488-96.

25. Halper J, Kjaer M. Basic components of connective tissues and extracellular matrix: elastin, fibrillin, fibulins, fibrinogen, fibronectin, laminin, tenascins and thrombospondins. Adv Exp Med Biol. 2014;802:31-47.

26. Ruoslahti E. RGD and other recognition sequences for integrins. Annu Rev Cell Dev Biol. 1996;12:697-715.

27. Miranda I, Silva-Dias A, Rocha R, Teixeira-Santos R, Coelho C, Gonçalves T, et al. Candida albicans CUG mistranslation is a mechanism to create cell surface variation. MBio. 2013;4(4):e00285-13.

28. da Costa KR, Ferreira JC, Lavrador MA, Baruffi MD, Candido RC. Virulence attributes and genetic variability of oral Candida albicans and Candida tropicalis isolates. Mycoses. 2012;55(3):e97-e105.

29. Silva S, Negri M, Henriques M, Oliveira R, Williams DW, Azeredo J. Adherence and biofilm formation of non-Candida albicans Candida species. Trends Microbiol. 2011;19(5):241-7.

30. Klis FM, Brul S, De Groot PW. Covalently linked wall proteins in ascomycetous fungi. Yeast. 2010;27(8):489-93.

31. Klis FM, Sosinska GJ, de Groot PW, Brul S. Covalently linked cell wall proteins of Candida albicans and their role in fitness and virulence. FEMS Yeast Res. 2009:9(7):1013-28.

32. Bouchara JP, Tronchin G, Annaix V, Robert R, Senet JM. Laminin receptors on Candida albicans germ tubes. Infect Immun. 1990;58(1):48-54.

33. Jakab E, Paulsson M, Ascencio F, Ljungh A. Expression of vitronectin and fibronectin binding by Candida albicans yeast cells. APMIS. 1993;101(3):187-93.

34. Sturtevant J, Calderone R. Candida albicans adhesins: Biochemical aspects and virulence. Rev Iberoam Micol. 1997;14(3):90-7.

35. Biasoli MS, Tosello ME, Luque AG, Magaró HM. Adherence, colonization and dissemination of Candida dubliniensis and other Candida species. Med Mycol. 2010;48(2):291-7.

36. Karkowska-Kuleta J, Kozik A. Moonlighting proteins as virulence factors of pathogenic fungi, parasitic protozoa and multicellular parasites. Mol Oral Microbiol. 2014;29(6):270-83.

37. de Groot PW, Bader O, de Boer AD, Weig M, Chauhan N. Adhesins in human fungal pathogens: glue with plenty of stick. Eukaryot Cell. 2013;12(4):470-81.

38. Gaur NK, Klotz SA, Henderson RL. Overexpression of the Candida albicans ALA1 gene in Saccharomyces cerevisiae results in aggregation following attachment 
of yeast cells to extracellular matrix proteins, adherence properties similar to those of Candida albicans. Infect Immun. 1999;67(11):6040-7.

39. Donohue DS, lelasi FS, Goossens KV, Willaert RG. The N-terminal part of Als1 protein from Candida albicans specifically binds fucose-containing glycans. Mol Microbiol. 2011;80(6):1667-79.

40. Nobbs AH, Vickerman MM, Jenkinson HF. Heterologous expression of Candida albicans cell wall-associated adhesins in Saccharomyces cerevisiae reveals differential specificities in adherence and biofilm formation and in binding oral Streptococcus gordonii. Eukaryot Cell. 2010;9(10):1622-34.

41. Rauceo JM, De Armond R, Otoo H, Kahn PC, Klotz SA, Gaur NK, et al.

Threonine-rich repeats increase fibronectin binding in the Candida albicans adhesin Als5p. Eukaryot Cell. 2006;5(10):1664-73.

42. Kapteyn JC, Hoyer LL, Hecht JE, Müller WH, Andel A, Verkleij AJ, et al. The cell wall architecture of Candida albicans wild-type cells and cell wall-defective mutants. Mol Microbiol. 2000;35(3):615-22.

43. Boisramé A, Cornu A, Da Costa G, Richard ML. Unexpected role for a serine/ threonine-rich domain in the Candida albicans Iff protein family. Eukaryot Cell. 2011;10(10):1317-30.

44. Jong AY, Chen SH, Stins MF, Kim KS, Tuan TL, Huang SH. Binding of Candida albicans enolase to plasmin(ogen) results in enhanced invasion of human brain microvascular endothelial cells. J Med Microbiol. 2003;52(Pt8):615-22.

45. Lopez CM, Wallich R, Riesbeck K, Skerka C, Zipfel PF. Candida albicans uses the surface protein Gpm1 to attach to human endothelial cells and to keratinocytes via the adhesive protein vitronectin. PLoS One. 2014;9(3):e90796.

46. Lee PY, Gam LH, Yong VC, Rosli R, Ng KP, Chong PP. Identification of immunogenic proteins of Candida parapsilosis by serological proteome analysis. J Appl Microbiol. 2014;116(4):999-1009.

47. Lee PY, Gam LH, Yong VC, Rosli R, Ng KP, Chong PP. Immunoproteomic analysis of antibody response to cell wall-associated proteins of Candida tropicalis. J Appl Microbiol. 2014;117(3):854-65.

48. Seweryn E, Pietkiewicz J, Szamborska A, Gamian A. Enolase on the surface of prokaryotic and eukaryotic cells is a receptor for human plasminogen. Postepy Hig Med Dosw (Online). 2007:61:672-82.

49. da Silva Neto BR, de Fátima da Silva J, Mendes-Giannini MJ, Lenzi HL, de Almeida Soares CM, Pereira M. The malate synthase of Paracoccidioides brasiliensis is a linked surface protein that behaves as an anchorless adhesin. BMC Microbiol. 2009:9:272

\section{Submit your next manuscript to BioMed Central and take full advantage of:}

- Convenient online submission

- Thorough peer review

- No space constraints or color figure charges

- Immediate publication on acceptance

- Inclusion in PubMed, CAS, Scopus and Google Scholar

- Research which is freely available for redistribution

Submit your manuscript at www.biomedcentral.com/submit 